\title{
Specialization issues of production of agrarian enterprises
}

\author{
Tatiana Vlasenko ${ }^{1, *}$, Vitaliy Vlasovets ${ }^{1}$, Sergiy Timofeev $^{2}$ and Anna Kravets ${ }^{2}$ \\ ${ }^{1}$ Kharkiv Petro Vasylenko National Technical University of Agriculture, 61002 Alchevski Str, \\ Kharkiv, Ukraine \\ ${ }^{2}$ Ukrainian State University of Railway Transport, 61000 Feierbakh Square 7, Kharkiv, Ukraine
}

\begin{abstract}
The relevance of the study is explained by the fact that the combination of branches of livestock farming and crop production within agrarian enterprises creates a certain complexity in the use of material, labour and land resources and makes it necessary to create an optimal ratio on the basis of the formation of the most perspective and efficient industries. However, the contradictory and controversial nature of the data on the impact of various interconnected factors, the presence of primarily theoretical modelling while determining the optimal level of specialization of agrarian enterprises does not allow to achieve a given level of efficiency and efficiency of functioning performance Therefore, the purpose of the research is to provide scientific substantiation of the efficiency improving directions of agrarian enterprises through their specialization improvement. They are the empirical basis of the structured choice of directions to increase the functioning efficiency of agrarian enterprises. For the crop production industry, the main direction that will increase the management efficiency is the crops productivity increase due to the production profitability increase for the most management conditions. It was determined that regional features are important for plant cultivation and animal husbandry sectors while determining the influence factors on specialization. It was found out that for both industries, the negative impact of labour security and ineffective management practices are typical, and state support through subsidies for agricultural enterprises does not guarantee the increase in the production efficiency.
\end{abstract}

\section{Introduction}

According to modern studies searching for tendency of the increase of agrarian enterprises efficiency, there is a sectoral structure that is the ratio of interdependence of certain leading industries (crop production, livestock farming) and sub-sectors, which reflect the integral system the agrarian enterprise production [1]. The functioning effectiveness of such a system at each level of specialization causes the necessity to create an optimal ratio on the basis of the creation of the most perspective and efficient industries [2].

\section{Problem Statement}

\footnotetext{
*Corresponding author: vlasovez@ukr.net
} 
However, the contradictory and controversial nature of the data on the impact of various interconnected factors, the presence of primarily theoretical modelling while determining the optimal level of specialization of agrarian enterprises does not allow to achieve a given level of efficiency and efficiency of functioning performance. Despite the wide range of applied theoretical models in the studied works, there are no practical recommendations for determining the impact of enterprises specialization on their functioning efficiency in dynamics.

\section{Research Questions}

The theoretical and methodological basis of the study is a systematic approach to studying the laws of development of agrarian enterprises in dynamics, the basic postulates of economic theory, macro- and microeconomics. The main tasks of the research are to determine the scientific principles of the sectoral structure formation of agrarian production and the peculiarities of its specialization levels formation, as well as the methodological principles substantiation for determining the optimality of the sectoral structure of agrarian enterprises in the dynamics.

\section{Purpose of The Study}

The purpose of the research is to provide scientific substantiation of the efficiency increasing directions of agrarian enterprises through their specialization improvement.

\section{Research Methods}

The analysis of the density of the scientific research, cluster and temporal analyses were used to estimate the scientometric data for the period of 1990-2019 to establish the timedivision of the connections between the clusters of the scientific directions of the most cited publications. This approach made it possible to establish the scientific priorities of the research on the specialization of agrarian enterprises.

\section{Findings}

The sectoral structure of agrarian enterprises is not sustainable. The ratio of industries is constantly changing under the influence of natural, economic and social conditions [3]. The analysis of the scientific research density aimed at studying the specialization of agricultural production in the world has allowed to outline the main factors that influence the formation of specialization levels of agrarian enterprises in the dynamics, namely: natural and climatic conditions, market conditions, labour supply level, development of agrotechnologies, material and technical support Regression and correlation analyzes are often used to determine the influence of factors on the resulting feature. Our research has established [4] that the use of regression and correlation analysis allows us to reliably describe processes regularities only in the presence of a normal population distribution, and the other factors immutability, which gives the stability of the basic dependence. However, when studying economical phenomena in dynamics, the population with normal distribution is rare, and at the feature compatibility - is practically absent. Therefore, for a further studies, a relatively new method, the statistical equations of dependencies [5], has been used. 
Using temporal analysis, clusters of scientific research on the specialization of agrarian enterprises (Fig. 1 a) and their main connections are established on the basis of the analysis of the most cited research (Fig. $1 \mathrm{~b}$ ).

The first cluster of research, based on the work of R. Pieri, D. Rama, L. Venturini [6] aimed at the studying of the impact of agrarian enterprises specialization on the industries competitiveness. The relationship between agrarian production factors and vertical specialization is studied in I. Ferto works. [3] Scientists R. Sarker and Y. Surry [2] on the base of I. Ferto research substantiated the need to take into account not only the influence of production factors, but also their intensity and product differentiation on the agrarian enterprises specialization. Studies by Bojnec S. made an assessment of the relationship of value added products and the enterprises specialization [7]. Despite the wide range of applied theoretical models in the works, there are no practical recommendations for determining the impact of enterprises specialization on their functioning efficiency in dynamics and determining the optimality of the sectoral structure.

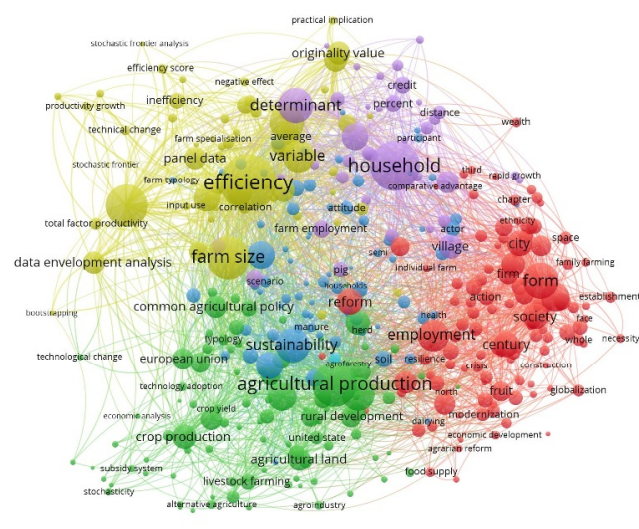

a)

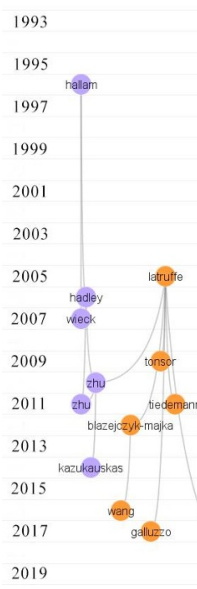

2019

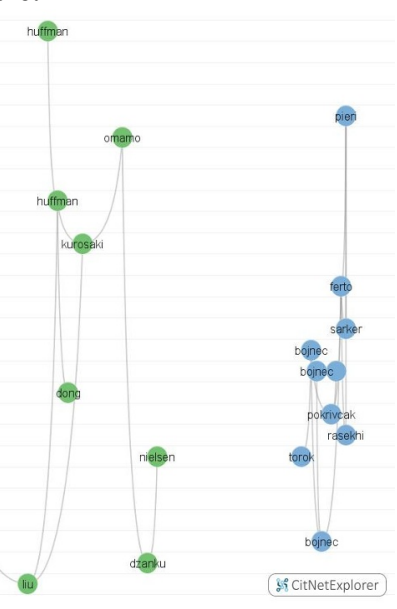

b)

Fig. 1. Clusters of scientific research (a) on the agricultural production specialization in the world (red and yellow - the most intense development, green and blue - less dynamics) and links between the scientific directions of the most cited authors (b) for the period of 1990-2019. Source: Web of Science Core Collection, Clarivate Analytics (Data Processed: April 10, 2019)

The second cluster of research is aimed at studying the influence of various factors on the specialization of the primarily crop production industry. It is based on the works of W. E. Huffman and R. E. Evenson focusing on the study of the factors influence (agrochemical prices, salaries, exploitation costs of agricultural machinery, farm sizes) and state programs on specialization and production efficiency [8]. They emphasize the special role of market factors in the sectoral structure formation. S. W. Omamo offers developing countries to focus primarily on the rational specialization of industries that have high transport costs when importing products into the country [9]. Increasing the efficiency of transportation by rural road networks is one of the effective ways of increasing small farms specialization. Empirical studies by T. Kurosaki aimed at the impact determining of the concentration of crop cultivation area on the specialization and diversification of the enterprises sectoral structure allowed to establish that the increase in the crops productivity mainly increases the production profitability [10]. Studies of this group of scientists covered, on the one hand, a significant historical interval of the various factors influence on specialization, but on the other hand, they did not take into account their specific effect in the context of agrarian production activity in Ukraine, as well as the formation of the sectoral structure of farms. 
The third cluster of research is devoted to the study of technical efficiency and specialization mainly of livestock enterprises on their financial figures of efficiency. Thus, on the basis of studies of the impact of a significant number of production efficiency factors D. Hallam and F. Machado have established that for Portugal, there is a stable correlation between the size of the dairy farm and the degree of specialization [11]. The average production efficiency varies within $60-70 \%$ and increases with the enterprises consolidation. D. Hadley studied the impact of technical efficiency and specialization on livestock farming and crop production in the UK [12]. He outlined two main groups. The first one concerns farms operating on the upper limit of profitability for which the technical efficiency increase quickly leads to the production efficiency increase. To the second - the enterprises for which the increase of technical efficiency leads to less intense dynamics. For both groups, it has been established that the herd size has primarily effect on the development of the livestock sector, and for both industries - the volume of credit commitments, the average age of workers, the level of specialization and ownership. For Polish farms, the influence of the technical effect and scale of production was studied by L. Latruffe, K. Balcombe, S. Davidova and K. Zawalinska [13]. They confirmed that the livestock sector is on average more sensitive to technical and scale effects than crop production. But for both industries, the negative impact of ineffective management practices is characteristic. It is established that the low level of education of workers employed in farms is one of the most important reasons of inefficiency of technical modernization method of agrarian production. The research was further conducted by L. Blazejczyk-Majka, R. Kala and K. Maciejewski, who considered the effect of technical efficiency on the farms for traditional EU countries and its new members [14]. It has been determined that the greatest efficiency is achieved at the expense of large farms, but those of the new EU member states at the same time had low scale efficiency, while those belonging to the traditional EU countries acted on a scale close to the optimal. In addition, it has been confirmed that longer period of agriculture under relatively stable conditions contributes to higher efficiency, regardless of the agricultural production type. On the other hand, in contrast to the approach where higher specialization contributes to greater efficiency, it has been found out that farms with crop production specialization are on average less effective than mixed farms, although the difference between efficiency decreases with the size increase.

The comparison of L. Latruffe and L. Blazejczyk-Majka studies shows that the data of the technical efficiency calculation are significantly dependent on the scale of the research carried out and have significant differences for the interstate, state and regional levels. In addition, the absolute value of maximum technical efficiency is not comparable. Some authors do not directly link technical and economic efficiency. A closer connection exists for dairy farms, and for the crop production it is less obvious. In addition, S.C. Kumbhakar, E.G. Tsionas and T. Sipilainen's studies in the Finnish dairy industry have shown that traditional production technologies are more efficient, as well as technically more than organic, which usually require state support. State support through subsidies for agrarian enterprises also does not guarantee efficiency increase. Thus, the share of subsidies in the total amount of factors has a negative impact on technical efficiency in Germany (the farms are expanding), but has little positive impact in Sweden (the specialization of farms is increasing) and practically does not affect the Netherlands.

\section{CONCLUSION}

The temporal analysis of research on management of agrarian enterprises specialization made it possible to reveal a number of tendencies that are characteristic for its various levels. It was established that while studying the problems of the impact of agrarian 
enterprises specialization on the competitiveness of industries, it is necessary to take into account not only the influence of production factors, but also their dynamics intensity and product differentiation. For the crop production industry, the main factor influencing the specialization level is the increase in crop yields, which increases the production profitability for the most farming conditions. Besides such factors as prices on agrochemicals, salary, agricultural machinery exploitation prices, the size of farms and state programs of technical support are secondary. It has been established that specialization increase for dairy farms (technical effect), along with their size increase (scale effect), positively influences the increase of production profitability, especially for regions with low prime cost. It is confirmed that the livestock farming industry is on average more sensitive to technical and scale effects than crop production. It has been determined that regional features are the most important for determining the influence factors both for the plant and livestock farming industries of the enterprise. Both industries are characterized by the negative impact of labour supply and ineffective management practices, and the state support through subsidies for agrarian enterprises does not guarantee increased production efficiency.

\section{References}

1. P. Sckokai, D. Moro, Modeling the reforms of the common agricultural policy for arable crops under uncertainty. AJAE, 88(1), 43-56 (2006)

2. R. Sarker, Y. Surry, Product differentiation and trade in agri-food products: Taking stock and looking forward. International Agricultural Trade and Development, (Hauppauge: Nova Science Publishers Inc., 39-80, 2007)

3. I. Ferto, Vertically differentiated trade and differences in factor endowment: The case of agri-food products between Hungary and the EU. JAE, 56(1), 117-134 (2005)

4. T.S. Skoblo, V.M. Vlasovets, Specific Features of the Formation of Structures in 60Kh2N4GDeF Precipitation-Hardening Steel. Materials Science, 12, 26-29 (2001)

5. T.V. Vlasenko, Modeliuvannia dynamiky rozvytku dlia udoskonalennia upravlinnia spetsializatsiieiu pidpryiemstva. Tekhnolohycheskyi audyt y rezerv proyzvodstva, 5/4(31), 9-15 (2016)

6. R. Pieri, D. Rama, L. Venturini, Intra-industry trade in the European dairy industry. European Review of Agricultural Economics, 24(3-4), 411-425 (1997)

7. S. Bojnec, I. Ferto, Agro-food trade competitiveness of Central European and Balkan countries. Food Policy, 34(5), 417-425 (2009)

8. W.E. Huffman, R.E. Evenson, Structural and productivity change in US agriculture, 1950-1982. Agricultural Economics, 24(2), 127-147 (2001)

9. A. Naseem, D.J. Spielman, S.W. Omamo, Private-Sector Investment in R\&D: A Review of Policy Options to Promote its Growth in Developing-Country Agriculture. Agribusiness, 26(1), 143-173 (2010)

10. T. Kurosaki Specialization and diversification in agricultural transformation: The case of West Punjab,1903-92. AJAE, 85(2), 372-386 (2003)

11. D. Hallam, F. Machado, Efficiency analysis with panel data: A study of Portuguese dairy farms. European Review of Agricultural Economics, 23(1), 79-93 (1996)

12. D. Hadley, Patterns in technical efficiency and technical change at the farm-level in England and Wales, 1982-2002. JAE, 57(1), 81-100 (2006)

13. L. Latruffe, K. Balcombe, S. Davidova, K. Zawalinska, Technical and scale efficiency of crop and livestock farms in Poland: does specialization matter? Agricultural Economics. 32(3), 281-296 (2005) 
14. L. Blazejczyk-Majka, R. Kala, K. Maciejewski, Productivity and efficiency of large and small field crop farms and mixed farms of the old and new EU regions. Agricultural Economics-Zemedelska Ekonomika, 58(2), 61-71 (2012) 